\title{
Я.I. Пенішкевич
}

Кафедра офтальмології імені Б.Л. Радзіховського (зав. - д.мед.н. Я.І. Пенішкевич) ВДНЗ Украӥни

“Буковинський державний медичний університет”, м. Чернівиі

\section{ВПЛИВ ЕЙКОЗАНОЇДІВ ТА БЛОКАТОРІВ ЇХ СИНТЕЗУ НА ІНТЕНСИВНІСТЬ ЛІЗИСУ ВИСОКОМОЛЕКУЛЯРНИХ БІЛКІВ У ВОЛОЗІ ПЕРЕДНЬОЇ КАМЕРИ ОКА ПРИ ПРОНИКНОМУ ПОРАНЕННІ СКЛЕРИ В ЕКСПЕРИМЕНТІ}

\begin{abstract}
Резюме. 3 метою вивчення впливу простагландинів, а також інгібіторів їх синтезу на протеолітичний лізис високомолекулярних білків у волозі передньої камери ока при проникному пораненні склери проведено досліди на 40 очах 40 кроликів породи Шиншила. Показано, що при проникній травмі склери інтенсивність лізису високомолекулярних білків не змінюється, проте колагеназна активність вологи передньої камери ока зростає впродовж усього періоду спостереження. Встановлено, що простагландини (PG) E1 i PG F2 $\alpha$ зменшують ступінь деградації високомолекулярних білків, PG E2 підвищує інтенсивність лізису азоказеїну за умов зниження інтенсивності протеолітичного розпаду колагену. Парацетамол, диклофенак і дексаметазон зменшують протеоліз високомолекулярних білків, але суттєво підвищують колагеназну активність вологи передньої камери ока у кроликів з проникним пораненням склери.
\end{abstract}

Ключові слова: око, склера, травма, простагландини, протеоліз.

Ушкодження заднього сегмента очного яблука супроводжується особливо тяжкими ускладненнями, коли високу гостроту зору можна зберегти лише за умови мінімальної інтенсивності проліферативних процесів в уражених запальним процесом структурах заднього сегмента ока [1], тобто основним чинником, що визначає тяжкість стану ока при цій патології, $\epsilon$ інтенсивність проліферативного компоненту [2]. Гістоморфологічна ознака післятравматичної субатрофії очного яблука - це розповсюджений фіброз, зумовлений заміщенням пошкоджених структур ока сполучною тканиною внаслідок дистрофічних, некробіотичних та запальних процесів [3]. Післятравматичне запаленя ока характеризується утворенням фіброзної тканини на основі нелізованих відкладень фібрину [4]. Отже, для прогнозу результатів лікування поранень заднього сегмента очного яблука великого значення набуває стан локального інтраокулярного протеолізу-фібринолізу, корекція порушень якого сприяє оптимізації перебігу післятравматичного запалення [5].

Мета дослідження: 3'ясувати вплив простагландинів, а також інгібіторів їх синтезу на протеолітичний лізис високомолекулярних білків (ВМБ) у волозі передньої камери ока при проник- ному пораненні склери.

Матеріал і методи. Робота виконана на 40 кроликах породи Шиншила масою 2-2,5 кг (вік - 11,5 року). Моделювання травми ока (проникне поранення склери) проводили за асептичних умов мікрохірургічним лезом під епібульбарною анестезією 0,5\% дікаӥном, поєднаною з ретробульбарною анестезією $2,0 \%$ розчином новокаӥну.

Простагландини (PG) E1, E2 та F2 $\alpha$ застосовували в інстиляиійних дозах відповідно: 115 нг 2 рази на день, 20 мкг одноразово і 250 нг 3 рази на день упродовж трьох діб (за винятком $P G F 2 \alpha$, який вводили впродовж двох тижнів). Парацетамол вводили в дозі 0,5 мг, діклофенак і дексаметазон - 0,05 мг упродовж двох тижнів (усі- шість разів на добу).

Забір вологи передньої камери ока проводили за асептичних умов під епібульбарною анестезією 0,5\% дікайном у динамічу 60-ти денного спостереження.

Визначення протеолітичної активності у волозі передньої камери ока проводилося методом лізису азосполук з використанням реактивів "Simko Ltd." (Україна). Принцип методу полягає в тому, щзо при інкубації азоальбуміну, азоказеїну або азоколу в лужному середовищі в присутністі інгібіторів та активаторів протеолізу, які

(C) Пенішкевич Я.I., 2015 
містяться у волозі передньої камери ока, відбувається ензиматичний лізис азосполук, активність якого оцінюється за ступенем забарвлення інкубачійного розчину [6].

Статистична обробка отриманих даних проведена на РС IBM 586 за допомогою "Excel-7".

Результати дослідження та їх обговорення. При проникній травмі склери підвищення ензиматичного розпаду ВМБ (табл. 1) відбувалося тільки на 14-ту добу експерименту, коли лізис азоказеїну (АКЗ) перевищував контроль на 42,2\%. Вплив PGE1 на 14-ту добу лікування знижував лізис АКЗ до контрольних величин, а на 3-тю і 60-ту добу спостереження казеїнолітична активність у волозі передньої камери (ПК) травмованого ока зменшувалася, відносно контролю, на 22,9 та 27,8\% відповідно. На 3-тю добу досліду PGE2 збільшував інтенсивність лізису ВМБ відносно такої у псевдолікованих тварин на 78,7\%, а на 7 - му і 14-ту добу лізис АКЗ перевищував контрольні показники відповідно на 64,7 та 38,5\%. Під впливом PGF2 $\alpha$ лізис ВМБ знижувався відносно контролю та даних у псевдолікованих тварин на 1-у, 3-тю і 14-ту добу спостереження і надалі нормалізувався, а наприкінці досліду був знову меншим, ніж у тварин контрольної групи. Подібна динаміка змін інтенсивності протеолітичної деструкції ВМБ спостерігалася при використанні парацетамолу, диклофенаку і дексаметазону.

Найбільш суттєвих змін зазнавала колагеназна активність вологи ПК ока (табл. 2). При проникній травмі склери інтенсивність лізису АЗК у травмованому оці була на 30-65\% меншою за контроль упродовж всього періоду спостереження. Зауважимо, що при проникній травмі склери PGE1 викликав додаткове пригнічення колагенолітичної активності, яка знижувалася

Таблиия 1

Динаміка змін лізису азоказеїну (мкМ азоказеїну на 1 мл за хв) у волозі передньої камери ока під впливом екзогенних простагландинів і при блокаді синтезу ейкозаноїдів за умов проникної травми склери, $(\mathbf{x} \pm \mathbf{S x})$

\begin{tabular}{|c|c|c|c|c|c|c|}
\hline $\begin{array}{l}\text { Cерії до- } \\
\text { сліджень }\end{array}$ & 1 доба & 3 доба & 7 доба & 14 доба & 28 доба & 60 доба \\
\hline $\begin{array}{l}\text { Контроль, } \\
\mathrm{n}=5\end{array}$ & $71,87 \pm 4,29$ & $63,06 \pm 2,58$ & $65,76 \pm 2,88$ & $63,29 \pm 2,56$ & $66,69 \pm 3,21$ & $68,42 \pm 3,34$ \\
\hline $\begin{array}{l}\text { Травма, } \\
\mathrm{n}=5\end{array}$ & $64,39 \pm 6,68$ & $71,48 \pm 7,32$ & $79,96 \pm 9,27$ & $89,97 \pm 9,39$ & $72,59 \pm 7,26$ & $62,04 \pm 6,12$ \\
\hline $\begin{array}{l}\text { Травма }+ \\
\text { PGE }_{1}, \\
\text { n=5 }\end{array}$ & $56,89 \pm 6,07$ & $48,62 \pm 4,77$ & $63,06 \pm 5,43$ & $\begin{array}{l}59,31 \pm 5,49 \\
*\end{array}$ & $55,52 \pm 5,90$ & $49,39 \pm 5,54$ \\
\hline $\begin{array}{l}\text { Травма }+ \\
\mathrm{PGE}_{2}, \\
\mathrm{n}=5\end{array}$ & $86,83 \pm 8,99$ & $\begin{array}{l}127,71 \pm 10,1 \\
6 \\
* *\end{array}$ & $\begin{array}{l}108,29 \pm 10,8 \\
5\end{array}$ & $87,66 \pm 8,46$ & $79,50 \pm 8,02$ & $72,37 \pm 8,32$ \\
\hline $\begin{array}{l}\text { Травма }+ \\
\mathrm{PGF}_{2 \alpha} \\
\mathrm{n}=5\end{array}$ & $\begin{array}{l}32,79 \pm 3,15 \\
* *\end{array}$ & $\begin{array}{l}39,74 \pm 3,83 \\
* *\end{array}$ & $\begin{array}{l}47,06 \pm 3,77 \\
*\end{array}$ & $75,83 \pm 9,82$ & $59,17 \pm 5,90$ & $53,62 \pm 5,00$ \\
\hline $\begin{array}{l}\text { Травма + пара- } \\
\text { цетамол, } \\
\mathrm{n}=5\end{array}$ & $\begin{array}{l}43,32 \pm 3,69 \\
*\end{array}$ & $\begin{array}{l}47,17 \pm 3,65 \\
*\end{array}$ & $\begin{array}{l}52,86 \pm 4,16 \\
*\end{array}$ & $\begin{array}{l}56,57 \pm 4,98 \\
*\end{array}$ & $56,36 \pm 4,84$ & $48,14 \pm 4,34$ \\
\hline $\begin{array}{l}\text { Травма + дик- } \\
\text { лофенак, } \\
\mathrm{n}=5\end{array}$ & $\begin{array}{l}39,63 \pm 4,32 \\
*\end{array}$ & $\begin{array}{l}42,11 \pm 4,32 \\
* *\end{array}$ & $\begin{array}{l}44,62 \pm 4,32 \\
* *\end{array}$ & $\begin{array}{l}58,02 \pm 5,06 \\
*\end{array}$ & $55,66 \pm 5,52$ & $48,19 \pm 4,27$ \\
\hline $\begin{array}{l}\text { Травма + декс- } \\
\text { аметазон, } \\
n=5\end{array}$ & $\begin{array}{l}42,09 \pm 3,92 \\
*\end{array}$ & $\begin{array}{l}44,74 \pm 4,16 \\
*\end{array}$ & $\begin{array}{l}48,16 \pm 4,34 \\
*\end{array}$ & $\begin{array}{l}61,41 \pm 4,89 \\
*\end{array}$ & $56,12 \pm 5,10$ & $47,94 \pm 4,47$ \\
\hline
\end{tabular}

Примітки:

- - ступінь вірогідності різниць показників відносно контролю:

$\bullet-\mathrm{p}<0,05 ; \bullet \bullet-\mathrm{p}<0,01 ; \bullet \bullet \bullet-\mathrm{p}<0,001 ;$

* - ступінь вірогідності різниць показників відносно даних групи тварин з травмою ока без лікування:

$*-\mathrm{p}<0,05 ; * *-\mathrm{p}<0,01 ; * * *-\mathrm{p}<0,001 ;$

$\mathrm{n}$ - кількість спостережень 
Таблиия 2

Динаміка змін лізису азоколу (мкМ азоколу на 1 мл за хв) у волозі передньої камери ока під впливом екзогенних простагландинів і при блокаді синтезу ейкозаноїдів за умов проникної

травми склери, $(\mathbf{x} \pm \mathbf{S x})$

\begin{tabular}{|c|c|c|c|c|c|c|}
\hline $\begin{array}{l}\text { Серії до- } \\
\text { сліджень }\end{array}$ & 1 доба & 3 доба & 7 доба & 14 доба & 28 доба & 60 доба \\
\hline $\begin{array}{l}\text { Контроль, } \\
\mathrm{n}=5\end{array}$ & $1,86 \pm 0,08$ & $1,88 \pm 0,09$ & $1,82 \pm 0,07$ & $1,90 \pm 0,11$ & $1,81 \pm 0,06$ & $1,87 \pm 0,09$ \\
\hline $\begin{array}{l}\text { Tравма, } \\
\mathrm{n}=5\end{array}$ & $0,65 \pm 0,08$ & $1,07 \pm 0,11$ & $1,23 \pm 0,13$ & $1,30 \pm 0,14$ & $1,05 \pm 0,11$ & $0,76 \pm 0,08$ \\
\hline $\begin{array}{l}\text { Tравма + } \\
\text { PGE }_{1}, \\
n=5\end{array}$ & $0,48 \pm 0,05$ & $0,67 \pm 0,11$ & $\begin{array}{c}0,53 \pm 0,05 \\
* * *\end{array}$ & $\underset{* *}{0,55 \pm 0,05}$ & $\underset{* *}{0,46 \pm 0,05}$ & $0, \underset{* *}{0,38 \pm 0,05}$ \\
\hline $\begin{array}{l}\text { Tpabma }+ \\
\text { PGE }_{2}, \\
\mathrm{n}=5\end{array}$ & $0,62 \pm 0,08$ & $\begin{array}{c}0,53 \pm 0,07 \\
* *\end{array}$ & $1,60 \pm 0,15$ & $0,98 \pm 0,11$ & $0,78 \pm 0,09$ & $0,58 \pm 0,07$ \\
\hline $\begin{array}{l}\text { Tравма }+ \\
\text { PGF }_{2 \alpha} \\
\text { n=5 }\end{array}$ & $0,93 \pm 0,11$ & $1,41 \pm 0,15$ & $1,62 \pm 0,15$ & $2,48 \pm 0,27$ & $1,05 \pm 0,13$ & $0,95 \pm 0,14$ \\
\hline $\begin{array}{l}\text { Травма + пара- } \\
\text { цетамол, } \\
n=5\end{array}$ & $0,83 \pm 0,08$ & $1,37 \pm 0,13$ & $1,61 \pm 0,15$ & $1,82 \pm 0,18$ & $1,30 \pm 0,13$ & $0,88 \pm 0,08$ \\
\hline $\begin{array}{l}\text { Травма + дик- } \\
\text { лофенак, } \\
n=5\end{array}$ & $0,95 \pm 0,11$ & $1,52 \pm 0,14$ & $1,77 \pm 0,16$ & $1,94 \pm 0,16$ & $1,42 \pm 0,13$ & $1,00 \pm 0,13$ \\
\hline $\begin{array}{l}\text { Травма + декса- } \\
\text { метазон, } \\
n=5\end{array}$ & $0,88 \pm 0,08$ & $1,47 \pm 0,09$ & $1,69 \underset{*}{ \pm 0,14}$ & $1,87 \pm 0,14$ & $1,35 \pm 0,15$ & $0,95 \pm 0,09$ \\
\hline
\end{tabular}

Примітки:

• - ступінь вірогідності різниць показників відносно контролю:

$\bullet-p<0,05 ; \bullet \bullet-p<0,01 ; \bullet \bullet-p<0,001$;

* - ступінь вірогідності різниць показників відносно даних групи тварин з травмою ока без лікування:

$*-\mathrm{p}<0,05 ; * *-\mathrm{p}<0,01 ; * * *-\mathrm{p}<0,001 ;$

$\mathrm{n}$ - кількість спостережень

відносно такої у псевдолікованих тварин на 3-тю добу досліду на $37,4 \%$, на 7-му - на $57,1 \%$, на 14 ту - на $57,7 \%$, на 28 -му - на $56,2 \%$, на 60 -ту - на 50,8\%. Внаслідок дії PGE2 лізис АЗК зменшувався майже вдвічі лише на 3-тю добу лікування. PGF2 $\alpha$ не змінював інтенсивність колагенолізу на 1-шу і 3-тю добу, нормалізував іiі на 7-му добу і значно - на 90,1\% - підвищував лізис АЗК на 14ту добу. Парацетамол нормалізував колагеназну активність у волозі ПК травмованого ока на 7-му і 14-ту добу лікування, але в інші періоди спостереження інтенсивність колагенолізу не вирізнялася від такої ж у псевдолікованих тварин. Диклофенак і дексаметазон підвищували лізис АЗК: на 3 -тю добу - на 41,8 та 37,4\%, на 7-му - на 43,8 та $37,1 \%$, на 14-ту - на 48,6 та 43,2\% відповідно. Проте після припинення лікування колагенолітична активність у травмованому оці знижувалася і була істотно меншою за контрольні величини.

Отже, при проникній травмі склери жоден 3 препаратів не виявляв здатності нормалізувати інтенсивність колагенолізу в травмованому оці.

Висновки. 1. При проникній травмі склери інтенсивність лізису високомолекулярних білків зростає на другий тиждень експерименту і перевищує контроль на $42,17 \%(\mathrm{p}<0,05)$, а інтенсивність лізису азоколу впродовж всього періоду спостереження $є$ на 30-65\% меншою за контроль. 2. Простагландин E1 знижує лізис високомолекулярних білків до контрольних величин на чотирнадцяту добу лікування, а на третю і шістдесяту добу, відповідно, на 22,9 та 27,8\%; одночасно викликає додаткове пригнічення колагенолітичної активності з третьої по чотирнадцяту добу експерименту на 37,4-57,7\% відповідно. 3. Простагландини F2 $\alpha$ зменшує ступінь деградації високомолекулярних білків у волозі передньої камери ока кроликів 3 проникною травмою склери на першу, третю, чотирнадцяту і шістдесяту доби спостереження і водночас сприяє значному - на 90,1\% підвищенню лізису азоколу на чотирнадцяту добу. 4. Простагландин Е2 підвищує інтенсивність лізису азоказеїну на 78,7-38,5\% (3-14 доби) за умов зменшення інтенсивності протеолітичного розпаду колагену майже вдвічі лише на третю добу лікування у волозі передньої камери ока кроликів 3 проникною травмою склери. 5. Парацетамол, диклофенак і дексаметазон зменшують протеоліз високомолекулярних білків на першу, третю і чотирнадцяту добу спостереження; 
диклофенак і дексаметазон підвищують лізис азоколу на третю (41,8 та 37,4\%), на сьому (43,8 та $37,1 \%)$ i на чотирнадцяту $(48,6$ та $43,2 \%)$ відповідно, у волозі передньої камери ока кроликів $з$ проникною травмою склери.

Перспективи подальших досліджень. Проведені експериментальні дослідження доводять зміни протеолітичної деградації високомолекулярних білків у волозі передньої камери травмованого ока, а також необхідність ії корекції сучасними медикаментозними засобами, що варто розглядати як доклінічний етап даного дослідження і потреби наступного вивчення цих процесів у клініці.

\section{Список використаної літератури}

1. Persistent Subretinal Fluid After Successful Full-Thickness Macular Hole Surgery: Prognostic Factors, Morphological Features and Implications on Functional Recovery / P.G. Tranos, P. Stavrakas, A.N. Vakalis [et al.] // Adv. Ther. - 2015. - V. 32(7). - P.705-714. 2. Пенішкевич Я.I. Зміни інтенсивності колагенолізу у волозі передньої камери ока за проникної травми склери, обтяженої введенням ендотоксину в скло-

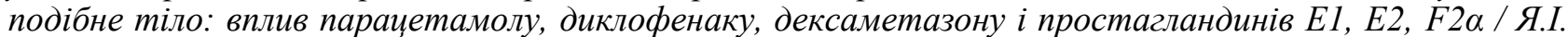
Пенішкевич // Наук. вісн. Ужгородського ун-ту. Серія “Медищина”. - 2002. - Вип. 17. - C. 161-164. 3. Immunohistochemical localization of urokinase-type plasminogen activator, urokinase-type plasminogen activator receptor and $\alpha 2$-antiplasmin in human corneal perforation: a case report / K. Sugioka, A. Kodama, K. Yoshida [et al.] // BMC Ophthalmol. - 2012. - Vol. 28(12). - P. 60. 4. Trypsin-mediated enzymatic degradation of type II collagen in the human vitreous / M. van Deemter, R. Kuijer, H. Pas Harm [et al.] // Mol. Vis. - 2013. - V. 20(19). - P. 1591-1599. 5. Пенішкевич Я.І. Інтенсивність лізису низькомолекулярних білків у волозі передньої камери ока при проникному пораненні правки і райдужки в експерименті: вплив простагландинів та інгібіторів синтезу ейкозаноїдів / Я.І. Пенішкевич // Клін. анатом. та оператив. хірург. - 2014. - Т. 13, № 2(48). - С. 85-88. 6. Кухарчук О.Л. Патогенетична роль та методи корекиії інтегративних порушень гормонально-месенджерних систем регуляиії гомеостазу натрію при патології нирок: автореф. дис... д-ра мед. наук: 14.03.05 / Одеський мед. ін-т / О.Л. Кухарчук. Oдеса, 1996. - 37 c.

\section{ВЛИЯНИЕ ЭЙКОЗАНОИДОВ И БЛОКАТО- РОВ ИХ СИНТЕЗА НА ИНТЕНСИВНОСТЬ ЛИЗИСА ВЫСОКОМОЛЛЕКУЛЯРНЫХ БЕ- ЛКОВ ВО ВЛАГЕ ПЕРЕДНЕЙ КАМЕРЫ ГЛАЗА ПРИ ПРОНИКАЮЩЕМ РАНЕНИИ СКЛЕРЫ В ЭКСПЕРИМЕНТЕ}

Резюме. С целью изучения влияния простагландинов, а также ингибиторов их синтеза на протеолитическую активность влаги передней камеры глаза при проникающем ранении склеры проведено исследование 40 глаз 40 кроликов породы Шиншилла. Показано, что при проникающем ранении склеры интенсивность лизиса высокомоллекулярных белков не изменяется, однако коллагеназная активность влаги передней камеры глаза увеличивается на протяжении всего периода эксперимента. Установлено, что простагландины (PG) E1 i PG F2 снижают степень деградации высокомоллекулярных белков, PG E2 повышает интенсивность лизиса азоказеина при снижении интенсивности протеолитического распада коллагена, а парацетамол, диклофенак и дексаметазон снижают протеолиз высокомоллекулярных белков, однако существенно повышают коллагеназную активность влаги передней камеры глаза у кроликов с ранением склеры.

Ключевые слова: глаз, склера, травма, простагландины, протеолиз.
THE INFLUENCE OF EICOSANOIDS AND INHIBITORS OF THEIR SYNTHESIS ON AQUEOUS HUMOUR HIGH-MOLECULAR PROTEINS LYSIS INTENSITY IN CASE OF EXPERIMENTAL PENETRATING SCLERAL INJURY

Abstract. With the aim to study the influence of prostaglandins and inhibitors of their synthesis on proteolytic activity of aqueous humour in case of penetrating scleral injury 40 eyes of 40 chinchilla rabbits were examined. The intensity of highmolecular proteins lysis in case of penetrating scleral injury has been indicated not to change, while collagen activity of aqueous humor increases throughout the whole period of the experiment. Prostaglandins (PG) E1 and PG F2 $\alpha$ were found to reduce degradation degree of high-molecular proteins, PG E2 increases the intensity of azocasein lysis with decreasing intensity of proteolytic collagen disintegration. Paracetamol, diclofenac and dexamethasone decrease the proteolysis of highmolecular proteins, but essentially increase collagenase activity of anterior chamber aqueous humour of rabbit eyes due to penetrating scleral injury.

Key words: eye, sclera, injury, prostaglandins, proteolysis.

Bukovinian State Medical University (Chernivtsi)

Надійшла 16.09.2015 p.

Рецензент - проф. Герасимюк I.Є. (Тернопіль) 